九州大学学術情報リポジトリ

Kyushu University Institutional Repository

\title{
New Oriental Weevils of the Tribes Rhamphini and Ochyromerini (Coleoptera, Curculionidae)
}

Kojima, Hiroaki

Entomological Laboratory. Faculty of Agriculture, Kyushu University

https://doi.org/10.5109/2613

出版情報: ESAKIA. 37, pp.121-134，1997-09-30. Entomological Laboratory，Faculty of Agriculture, Kyushu University バージョン：

権利関係 : 


\title{
New Oriental Weevils of the Tribes Rhamphini and Ochyromerini (Coleoptera, Curculionidae) "1
}

\author{
Hiroaki K o I IM A \\ Entomological Laboratory, Faculty of Agriculture, \\ Kyushu University, Fukuoka, 8 12-8 1 Japan
}

\begin{abstract}
Two new genera and three new species of the tribes Rhamphini and Ochyromerini are described from the Oriental region. Morimotonomizo gen. nov. (Rhamphini), type species Hyporhynchaenus sphinxioides Morimoto and Miyakawa, 1996 is described, with additional species M. flacourtiae (Marshall, 1957), comb. nov. from Rhynchaenus and M. fasciatus sp. nov. from Thailand. Zmachra Pascoe, 1873 is synonymized with Hyporhynchaenus Voss, 1940, syn. nov., and Imachralouraceae (Voss, 1940) is transferred from Rhynchaenus (Hyporhynchaenus). Kasturazo gen. nov. (Ochyromerini) is described with type species Katsurazo flabellicornis sp. nov. (East Malaysia: Sabah), and including also Katsurazo morimotoi sp. nov. (East Malaysia: Sabah).

Key words: Taxonomy, Coleoptera, new taxa, Curculionidae, Rhamphini, Ochyromerini, Oriental region.
\end{abstract}

Weevils of the tribes Rhamphini and Ochyromerini are abundant in the tropics of the Old World: relatively a few species of the former and only one introduced species of the latter (Warner, 1961) are found in the Nearctic region. The tribe Rhamphini is a characteristic compact group, characterized by having the hind femora swollen and modified for jumping with metafemoral spring. The classification is rather better established at generic than specific levels. Cladistic analysis of the East Asian genera was recently published by Kojima \& Morimoto (1996a). In their analysis, one of the smallest genera, Hyporhynchaenus Voss, was identified as the sister-group of Tachyerges Schoenherr, based on the second species described by Morimoto \& Miyakawa ( 1996). However, more recent examination has shown that the two species of Hyporhynchaenus, are not congereric, and the type species is a member of Zmachra Pascoe. Concequently, Hyporhynchaenus and Imachra are synonymised here, and a new genus is proposed for Hyporhynchaenus sensu Kojima et Morimoto (nec Voss, 1940).

On the other hand, the tribe Ochyromerini is rather less well-known taxonomically. Although Kojima \& Morimoto (1994-) initiated systematic work on this tribe of the East Asian fauna, there remain many taxa awaiting description even at generic level. Recently I

1) Contribution from the Entomological Laboratory, Faculty of Agriculture, Kyushu University, Fukuoka (Ser. 5, No. 4). 
discovered a previously unknown genus including some species which have specially modified antennae so far not known in weevils.

The abbreviations used in the present paper are as follows: BMNH-The Natural History Museum, London; ELKU-Entomological Laboratory, Kyushu University; NMNH-National Museum of Natural History, Leiden.

\section{Tribe RHAMPHINI}

\section{Morimotonomizo gen. nov.}

Hyporhynchaenus (nec Voss, 1940): Morimoto \& Miyakawa, 1996: 79. — Kojima \& Morimoto, 1996a: 111 (key), 113. Type species: Hyporhynchaenus sphinxioidrs Morimoto \& Miyakawa, 1996: 80, comb. nov.

Description. Body ovate. Eyes subcontiguous to narrowly separated by linear frons. Rostrum with antennal scrobes on sides. Antennae with 7 segments in the funicle; club usually loosely segmented. Prothorax widest at base. Legs with femora each usually armed with a spine-like tooth on fore and middle pairs; tibiae uncinate on fore and middle pairs. Prosternum usually with coxae separated. Tergite 7 with plectral tubercles for stridulation in 2 or 3 pairs anteriorly. Spermatheca with gland located in the middle of the body.

Comments. Hyporhynchaenus was established by Voss (1940) as a subgenus of Rhynchaenus from Java, but was raised to generic rank by Anderson (1989) because the antennae have 7 funicular segments instead of 6 in Rhynchaenus. This treatment was followed by Morimoto \& Miyakawa (1996) and they described the second species from West Malaysia. Examination of the type species of this genus, however, reveals it to be a member of Imachra Pascoe and Hyporhynchaenus is therefore a synonym of the latter. The second species, H. sphinxioides, differs from the type species in the following points: fore and middle femora each armed with a spine-like tooth and fore and middle tibiae uncinate. This species is closer to Tachyerges than Imachra, as was indicated by the sister-group relationship between it (as Hyporhynchaenus sphinxioides) and Tachyerges proposed by Kojima \& Morimoto (1996a).

M. sphinxioides has immaculated derm, a loosely segmented antennal club and narrowly separated fore coxae in addition to the characters mentioned above. However, members of a new species collected from Thailand have maculated derm and edentate femora, and are in this very similar to members of Tachyerges, except that the procoxae are narrowly separated.

The Javanese species Rhynchaenus flacourtiae Marshall (1957) has 7 funicular segments in the funicle rather than 6 segments as in other Rhynchaenus and Orchestes. The systematic position of this species was not settled by Kojima \& Morimoto ( 1996a). Although the procoxae are contiguous, this species should also be classified in Morimotonomizo because of the following features: fore and middle femora armed with spine-like tooth, fore and middle tibiae uncinate and spermathecal gland attached near the middle of the body. 

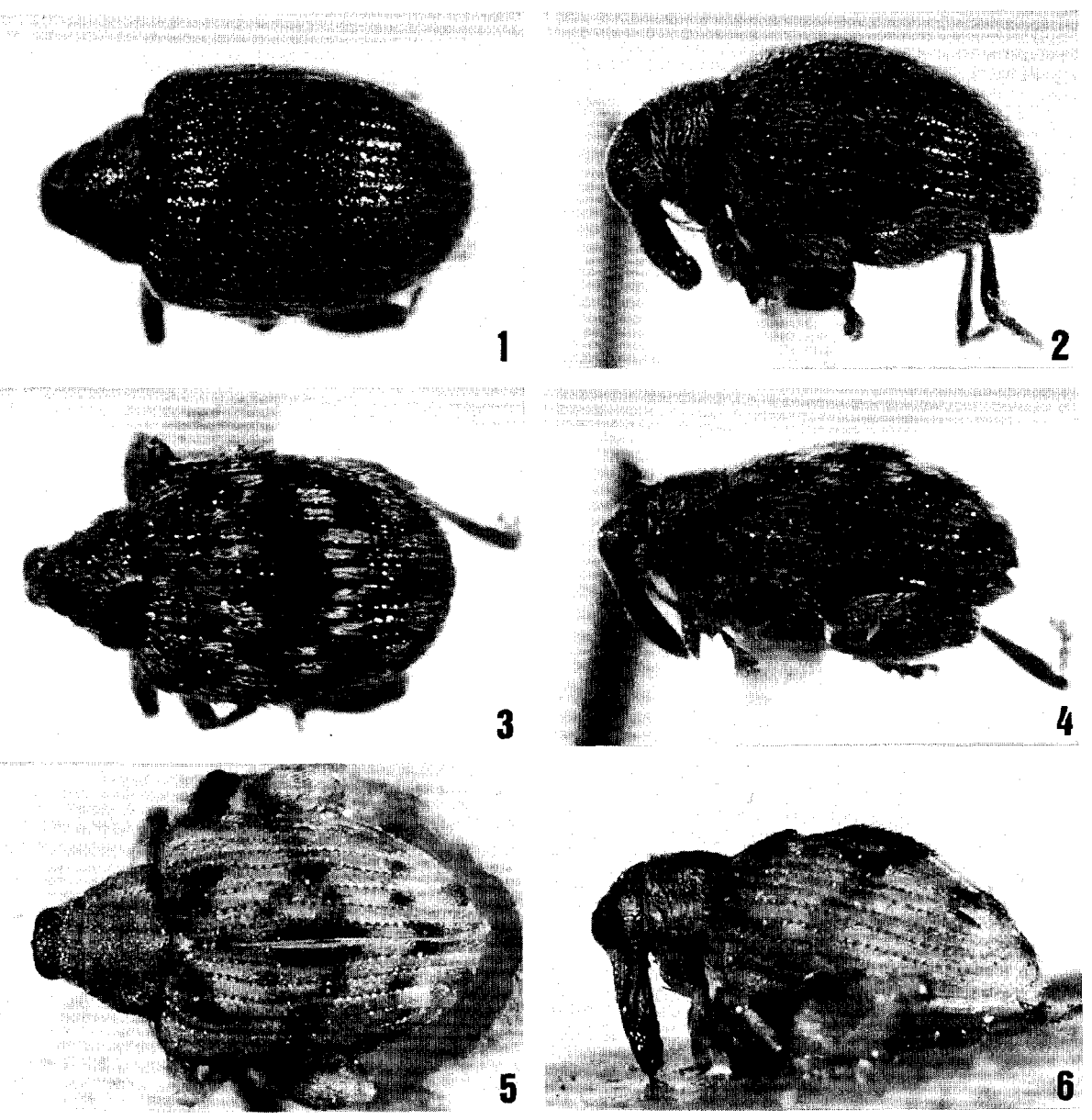

Figs. 1-6. Habitus photos of Morimotonomizo spp. 1-2, M. sphinxioides, male; 3-4, M. maculatus, female (holotype); 5-6, M. flacourtiae, female (holotype ).

The key to genera provided by Kojima \& Morimoto (1996a: 1 10-112) must be modified as follows:

7(14) Antennae with funicle 7-segmented or, if apparently 6-segmented, club with 1st segment much longer than the others by the fusion of 7 th of funicle with it. Pronotum and elytra usually without erect setae at sides. Fore and middle tibiae uncinate at tip. Spermatheca with gland distant from duct.

8(11) Antennae inserted before the middle of rostrum in male, funicle with 7 th segment longer than broad. Hind wing functional. normal in size. Abdominal tergites 5-7 with spicule patches, that on 7th reduced in size. with two, rarely three pairs of plectral tubercles on anterior margin of 7 th tergite. Spermatheca with gland located near middle of capsule. 
9(10) Antennae with club ovate, each segment transverse. Prosternum with coxae always contiguous. Femora not armed with tooth. Salicaeae-feeder.

Tachyerges Schoenherr

10 (9) Antennae with club loosely segmented. Prosternum with coxae usually separate, but if contiguous, at least in fore and middle femora armed with a spine-like tooth. Morimotonomizo gen. nov.

11(8) Antennae inserted in the middle of rostrum or in forehead, funicle with 7 th segment transverse, close to or fused with club. Tergum with 7 th tergite without plectrum. Hind wing reduced in size. Spermatheca with gland inserted in apical half of capsule.

12(13) Head strongly bent between forehead and rostrum, so rostrum always retracted between fore coxae. Eyes approximate dorsally. Antennae inserted in forehead, not geniculate, with oval scape as long as 1 st segment of funicle. Scutellum bare or thinly clothed with hairs. Hind femora distinctly swollen, with spiraled apodeme. Pronotum with coxae separate. but usually concealed by rostrum. Posterior margins of ventrites 2-4 straight. Aedeagus not strongly bent ventrally. Spermatheca with gland located on the middle or beyond the middle of capsule.

Rhamphus Clairville

13( 12) Head normal, rostrum perpendicular to the axis of body. Eyes more or less separated. Antennae inserted in rostrum, geniculate, scape much longer than 1st segment of funicle. Scutellum, lateral; pieces of meso- and metathorax densely covered with white plumose scales. Hind femora slightly swollen, with J-shaped apodeme. Prosternum with coxae contiguous. Venterites 2-4 with posterior margins not straight at sides. Aedeagus strongly bent ventrally. Spermatheca with capsule narrowed to the apex, gland located close to apex. ................ Isochmus Thomson

14(7) Antennae with funicle 6-segmented. Pronotum and elytra often with erect setae at sides. Tergum with 7 th segment more or less projecting in middle of anterior margin.

15(18) Fore and middle tibiae unarmed or mimutely uncinate at tip, femora without denticle or spine. Abdominal tergites 4-7 with spicule patches, smaller on tergites 4 and 7,7 th with plectral tubercles in a pair of rows. Derm yellowish to reddish brown. Rostrum not received in breast in repose.

16(17) Tibiae unarmed at tip. Spermatheca with capsule slender, gland located near middle.

Indodinorrhopalus Pajni \& Sood

17(16) Fore and middle tibiae minutely uncinate in middle of apical margin. Spermatheca with weak lateral gland lobe near base, with gland located on it. ................................. Rhynchaenus Clairville \& Schellenberg

18(15) Fore and middle tibiae each with a large sickle-shaped uncus near apex of dorsal edge, fore and middle femora often with denticle bearing a spine. hind femora often with denticles bearing long setae or spine. Abdominal tergites 5 and 6 with spicule patches, 7th tergite bilobed at middle of anterior margin, each lobe bearing a plectral tubercle. Derm various in color. Rostrum received on breast in repose. . . ........... Orchestes Illiger 
The biology of this genus is hardly known except for Morimotonomizo flacourtiae, specimens of which were bred from the fruits of Flacourtia of family Flacourtiaceae (Marshall, 1957) unlike most species of the tribe, which mine leaves as larvae.

Etymology. The generic name is a combination of Morimoto and nomizo, of which the latter means flea weevil in Japanese. This name is dedicated with gratitude to Dr. Katsura Morimoto for his retirement of Kyushu University, and is masculine in gender.

Distribution. Thailand, West Malaysia, Indonesia (Java).

\section{Key to Species}

1(4): Fore and middle femora each with a minute spine-like tooth.

2(3): Hind femora edentate. Fore coxae narrowly separated. Derm black; elytra without maculation; striae normal. West Malaysia.

sphinxioides (Morimoto \& Miyakawa)

3(2): Hind femora each with a tooth, as on the anterior 2 pairs. Fore coxae contiguous. Derm yellowish brown; elytra with tufts of dark setae on intervals 1, 3, 4 and 5; striae somewhat sinuate due to tufts. Indonesia: Java.

flacourtiae (Marshall)

4(1): Femora edentate. Fore coxae narrowly separated. Derm black, elytra fasciate. Thailand.

fasciatus sp. nov.

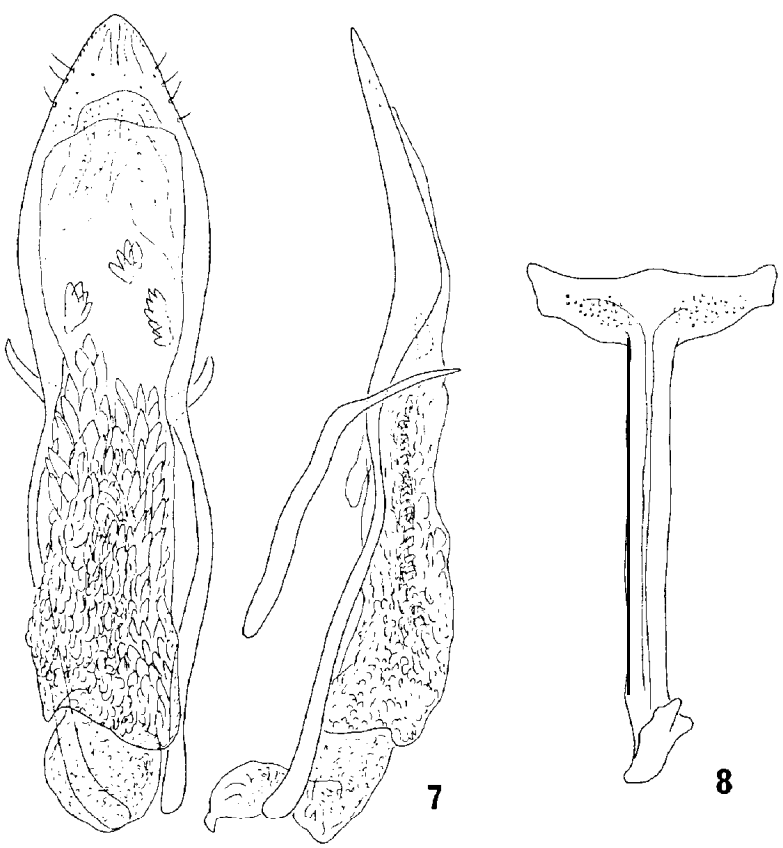

Figs. 7-8. Male genitalia of Morimotonomizo sphinxioides. 7. Aedeagus; 8 , spiculum gastrale. 


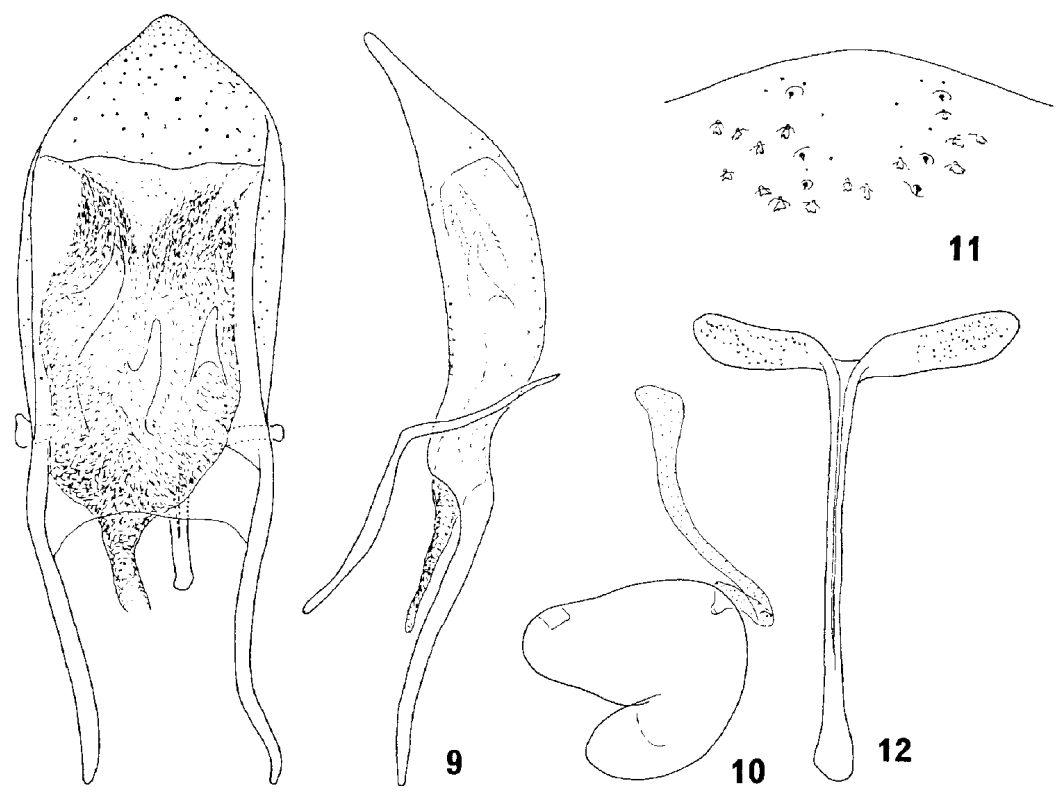

Figs. 9-12. Structure of Morimotonomizo flacourtiae. 9. Aedeagus: 10. spermatheca; 11, apical part of tergite 7, male; 12, spiculum gastrale.

Morimotonomizo sphinxioides (Morimoto \& Miyakawa), comb. nov. (Figs. 1-2, 7-8)

Hyporhynchaenus sphinxioides Morimoto \& Miyakawa, 1996: 80 (figs. 50-53). _ Kojima \& Morimoto, 1996a: 113 (figs. 15, 22, 49).

See Morimoto \& Miyakawa (1996) for description.

Specimens examined. WEST MALAYSIA. 2 males and 1 female, Bukit Larut, near Taiping, West Malaysia, 25-27.vii.1995, H.Kojima leg. (incl.holo- and paratype. ELKU, Type No.3038).

Distribution. West Malaysia.

Biological note. Specimens were captured by sweeping leaves of trees using an insect net with long rod about $6 \mathrm{~m}$ in length.

Morimotonomizo flacourtiae (Marshall), comb. nov.

(Figs. 5-6, 9-12)

Rhynchaenus flacourtiae Marshall, 1957: 61 (fig. 1). — Kojima \& Morimoto. 1996a: 116.

See Marshall (1957) for description.

Type data. Holotype male, BMNH, on card, with labels: "Type" (disc with red border)/ "L. G. E. Kalshoven; Java 250 M.; Buitenzorg; 1919"/ "Bred from: roekem 
fruits (Flacourtia)" (handwritten)/ "Rhynchaenus; flacourtiae, Mshl.; TYPE male (mark)" (handwritten).

Specimens examined. INDONESIA: JAVA. 2 males and 2 females, same data as holotype (holo- and paratypes, BMNH). 1 male and 2 females, same data as holotype (paratypes, NMNH). 2 exs., same data as holotype (NMNH). 7 exs.. W.Java.Bogor. 1919, leg.Kalshoven, plant nutrix Flacourtia fruit, ex larvae (NMNH).

Distribution. Indonesia (Java).

Biological note. Weevils were bred from the fruits of Flacourtia of family Flacourtiaceae (Marshall, 1957).

\section{Morimotonomizo fasciatus sp. nov.}

(Figs. 3-4)

Description. Female. Black, antennae and tarsi reddish brown; derm clothed with recumbent white and dark hairy scales and subrecumbent to suberect greyish. greyish brown to dark bristles, white hairy scales a little denser on lateral part behind each eye. and on fore coxae, scutellum and mesepimera, and forming four transverse bands on elytra as follows: faintly across basal and apical margins and zigzagging across a little before the middle between side margins and a little behind the middle between intervals 1 and 5, greyish to greyish brown bristles a little denser before the scutellum on pronotum.

Head with dense punctures, each puncture with a recumbent bristle excepting lateral part; forehead between eyes linear, dilated anteriorly and posteriorly. Rostrum weakly curved on dorsal surface, a little longer than pronotum (13: 10), tapered apically in lateral aspect; dorsum with 5 carinae on basal half, intervening sulci with setae, without setae and shiny on apical half. Antennae inserted a little before the middle of rostrum: scape just failing to meet eye, nearly as long as basal 5 segments of funicle combined, funicle with first segment a little more than twice as long as broad, second $3 / 5$ times as long as first. third $2 / 3$ times as long as second, fourth to seventh subequal in length, a little shorter than third; club 2.5 times as long as broad, about as long as basal 4 segments of funicle combined.

Prothorax 1.6 times as wide as long, widest at the base, weakly and roundly narrowing to weak subapical constriction; dorsum densely punctate. each puncture with a subrecumbent bristle, and with recumbent white setae on each lateral part, anterior and posterior corners each with a dark, long erect seta. Scutellum longer than broad, clothed with recumbent white hairs. Elytra 1.2 times as long as wide, widest a little before the middle; striae strongly punctate and sulcate; intervals a little wider than striae, each with row of subrecumbent to suberect bristles in the middle. Pygidium exposed at apical part.

Legs with femora edentate, hind femora twice as long as broad. Prosternum with coxae narrowly separated. Mesosternal process nearly as wide as a coxa.

Male. Unknown.

Length: $2.0 \mathrm{~mm}$.

Holotype female (Type No. 3053, ELKU), Mae Hong Son, Thailand. IO- 12. vii. 1995, H. Kojima leg.

Distribution. Thailand. 


\section{Tribe OCHYROMERINI}

Katsurazo gen. nov.

Type species: Katsurazo flabellicornis sp. nov.

Description. Body somewhat flattened dorso-ventrally. Derm clothed with recumbent fine setae and scaly setae. Head without constriction behind eyes; forehead between eyes nearly as wide as base of rostrum. Eyes strongly convexly produced from side of head. Antennal scrobes with two dorsal carinae, upper carina distinct, directed to lower part of eye, and lower carina weaker, directing to beneath the base of eye. Antennae often abnormal in male: funicle and club flattened, strongly dilated laterally and concave on ventral side; scape reaching eye; funicle composed of 7 segments. Prothorax widest before middle. Elytra oblong ovate, separately rounded at apex. Pygidium moderately broadly exposed. Legs with femora each armed with a triangular tooth, with a few erect setae beyond the tooth when the tooth is larger; fore tibiae uncinate and sharply angulate at inner apical angle, middle tibiae uncinate with inner angle sharply pointed at the apex. hind tibiae indistinctly uncinate; claws widely divergent, each with a broad flat tooth. Prosternum with coxae located near base. Metasternum and ventrite 1 flattened or depressed in the middle in male. Venter with ventrite 5 shorter than 3rd and 4 th combined.

Comments. This genus contains three species, of which two are peculiar in having specially modified unusual antennae, although the third one has normal antennae. Initially the author thought that these differences were a sexual dimorphism, but all specimens were determined as male. Although this genus seems to be heterogeneous because of the significant diversity in the structure of antennae, the third species is considered to be closely related to one of the others in characters other than the antennae and shares with the other species a characteristic structure of the tibial apex. Therefore. the author treats all of them as congeneric. It is not certain whether the unusual antennae occur in female. and unclear what its function is.

Katsurazo may be close to Heterochyromera Kojima and Morimoto (1996b) and Aedenus Voss $\left(1953^{*}\right)$ in having the following common characters: the derm is clothed with scaly setae, the eyes are convex, the antennae have 7 segments in the funicle. the pygidium is moderately broadly exposed and the venter with posterior margins of ventrites 2-4 are broadly curved caudad at sides. This new genus is, however. separable from them by the structure of the apical part of the tibiae, which are angulated in the fore pair and sharply pointed in the middle pair at the inner apical margins.

Etymology. The generic name is a combination of Katsura. the first name of Dr. Katsura Morimoto and $z o$, an abbreviated name of weevils among Japanese coleopterists. and is masculine in gender.

Distribution. East Malaysia (Sabah), Indonesia (Sumatra).

* Although Voss (1953) established this genus in the tribe Acalyptini. he must have been misled by the exposed pygidium. This genus is, therefore, newly transferred to the tribe Ochyromerini (new tribe assignment). 


\section{Key to Species (males)}

1(2): Antennae with funicle and club normal. Derm dark brown, antennae and legs a little paler. Elytra subparallel-sided in basal half. Legs with femora each with a small triangular tooth, without erect setae beyond it. Length: $2.8 \mathrm{~mm}$. Indonesia: Sumatra.

2(1): Antennae with funicle and club specially modified. Legs with femora each with a larger triangular tooth, with a few erect setae beyond it. Length: more than $4.0 \mathrm{~mm}$.

3(4): Derm light reddish brown. Body oblong-ovate, prothorax 1.1 times as wide as long, elytra a little more than 1.5 times as long as wide. Antennae unusually dilated from 4th segment of funicle. East Malaysia: Sabah.

*....... flabellicornis sp. nov.

4(3): Derm dark brown. Body ovate, prothorax 1.3 times as wide as long. elytra a little shorter than 1.5 times as long as wide. Antennae unusually dilated from 2nd segments of funicle. East Malaysia: Sabah. ....... morirnotoi sp. nov.

\section{Katsurazo flabellicornis sp. nov.}

(Figs. 13-17)

Description. Male. Light reddish brown; derm clothed with fine recumbent pale settle and recumbent yellowish grey scaly setae.

Head without setae behind eyes; forehead between eyes as wide as base of rostrum. clothed with scaly setae, with a median carina extending to rostrum. Rostrum shorter than pronotum (4:5); dorsum parallel-sided, with 5 distinct carinae behind the level of antennal insertion, intervening sulci with scaly setae. Antennae inserted at apical $1 / 4$ of rostrum; scape clavate and weakly concave at the apex of anterior margin: funicle with first segment 1.5 times as long as broad, a little longer than second, third to sixth gradually broadening to the apex of sixth segment, flattened from fourth segment to club. third to fifth transverse, subequal in length, about half as long as second, sixth longest. seventh transverse, gradually narrowing from sixth; club nearly as long as sixth and seventh segments of funicle combined.

Prothorax 1.1 times as wide as long, widest at apical 1/3, gradually narrowing to the base, constricted at the apex; dorsum clothed with fine recumbent setae. densely. but shallowly punctate, each puncture bearing a recumbent scaly seta. Scutellum a little longer than wide, clothed with recumbent setae. Elytra a little more than 1.5 times as long as wide, slightly widening from the shoulder to the middle; striae closely punctured and weakly sulcate; intervals wider than striae, clothed with fine recumbent setae and two rows of scaly setae. Pygidium clothed with recumbent scaly setae. Legs with femora clothed with fine recumbent setae and recumbent scaly setae, each with a large triangular tooth, with a few erect setae beyond the tooth, fore pair with small tooth on ventral side basal to the large tooth; tibiae clothed with recumbent setae, fore pair curved at basal half. slightly dilated internally a little before the middle, middle pair shortest. curved at the base, dilated internally, widest a little before the middle, thence distinctly concave internally to apex, hind pair concave and with a dull projection at apex of inner side. with 

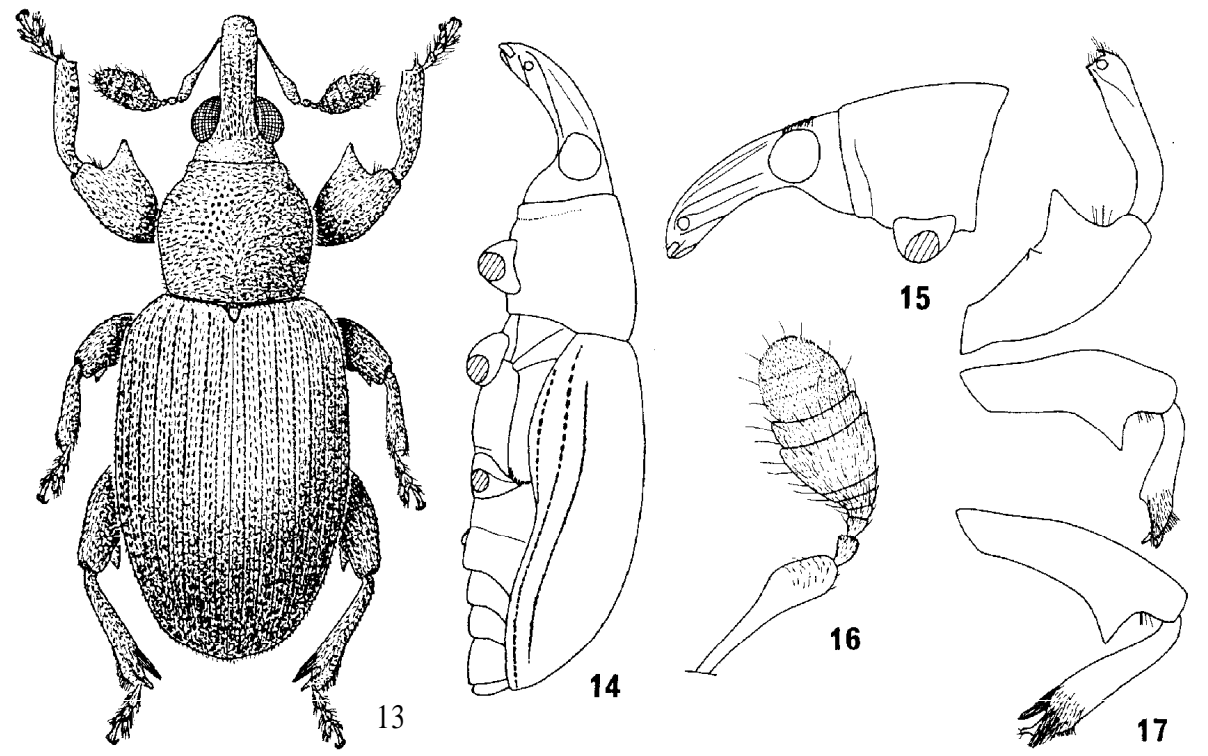

Figs. 13-17. Habitus and structure of Katsurazo flabellicornis. 13. Habitus: 14. ditto. lateral; 15, head and prothorax, lateral; 16, antenna; 17, legs.

a tuft of long hairs on dorsum, clothed with long setae at the apex of ventral side: hind tarsi clothed with long hairs underneath.

Underside clothed with fine recumbent setae, those of lateral pieces of meso- and metasternum and venter with scaly setae; metathorax and first ventrite depressed in the middle, second ventrite with a longitudinal, flat projection at basal half.

Female. Unknown.

Length: $4.2 \mathrm{~mm}$.

Holotype male (Type No. 3054, ELKU), Bundu Tuhan, Sabah. East Malaysia. 4. viii. 1983, Y. Johki leg. (flower of Triadica sebifera). Paratype. 1 male. Sepilok. Sandakan, Sabah, East Malaysia, 7. viii. 1985, Y. Johki leg. (at light).

Distribution. East Malaysia (Sabah).

\section{Katsurazo morimotoi sp. nov.}

(Figs. 18-22)

Description. Male. Dark brown, antennal scape and tarsi a little paler: derm clothed with fine recumbent pale setae and recumbent dark, irregularly yellowish grey scaly setae.

Head finely punctate; forehead between eyes a little narrower than base of rostrum. coarsely punctured, with a median carina extending to rostrum. Rostrum a little longer than pronotum (6:5), subparallel-sided to the middle, gradually widening to antenna1 insertions, thence rapidly narrowed and shortly parallel-sided at the apex; dorsurn confluently punctured, with a median and two weak carinae on each side behind the antennal insertions, intervening sulci with recumbent scaly setae. Antennae inserted at 
apical 1/4 of rostrum; scape clavate at apical half; funicle with first segment broader than long, flattened from second segment, dilated latero-internally from second to the base of sixth, thence narrowing to club, second a little longer than first. third shortest. a little shorter than second, fourth nearly as long as second and third combined, fifth about half as long as fourth, sixth largest, becoming longer latero-internally, as long as first to fifth combined in maximum length, seventh becoming shorter latero-internally. half as long in minimum length as maximum length; club nearly as long as the shortest length of sixth funicle segment.

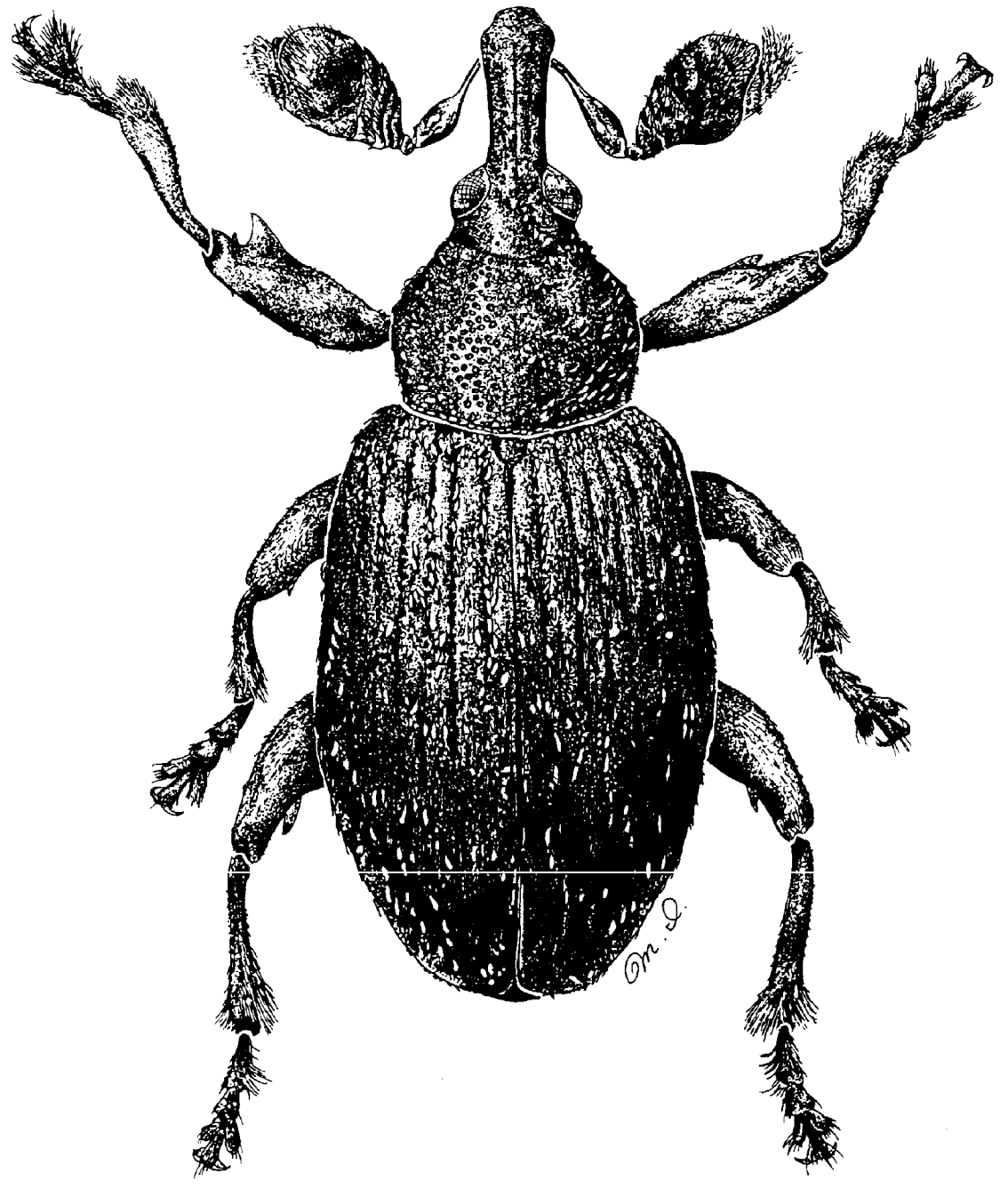

Fig. 18. Katsurazo morimotoi sp. nov. 
Prothorax 1.3 times as wide as long, widest at apical 1/3, narrowing to base, weakly constricted at apex; dorsum densely, but shallowly punctate, each puncture bearing a dark scale-like seta, setae irregularly and sparsely yellowish grey, remaining area clothed with fine recumbent pale setae. Scutellum a little longer than wide, clothed with recumbent pale setae. Elytra a little less than 1.5 times as long as wide, slightly widening from the shoulder to middle; striae closely punctured, but faintly sulcate; intervals much wider than striae, clothed with fine recumbent pale setae and a few rows of recumbent blackish, irregularly and sparsely yellowish grey scaly setae, yellowish grey setae a little denser at base. Pygidium exposed at the apex, clothed with yellowish brown and blackish scaly setae. Legs with femora clothed with fine recumbent pale setae and yellowish brown scaly setae, each femur armed with a large triangular tooth, those of hind one a little greater than the anterior ones, with a few erect setae beyond the tooth: tibiae clothed with fine recumbent setae, fore pair weakly sinuate externally, weakly dilated internally a little before the middle; middle pair shortest, slightly dilated internally a little before the middle. densely clothed with pale setae at the apex; hind pair slender, clothed with long pale setae at the apex of inner angle; hind tarsi with first segment densely clothed with yellowish brown long setae underneath.

Underside clothed with fine recumbent pale setae, lateral pieces of meso- and metathoraces and venter with yellowish brown scaly setae; metasternum and first ventrite broadly depressed in the middle, second ventrite with short, flat projection at the base, fifth with a pair of small tufts at the apex.

Female. Unknown.

Length: $5.8 \mathrm{~mm}$.
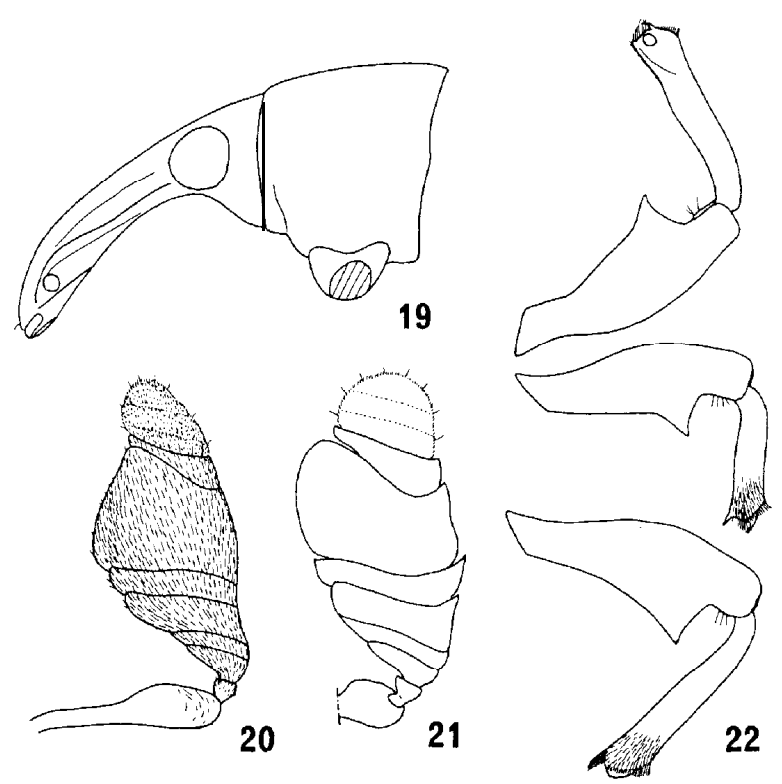

Figs. 19-22. Structure of Katsurazomorimotoi. 19, Head and prothorax. lateral: 20, antenna; 21, ditto, dorsal; 22, legs. 
Holotype female (Type No. 3055, ELKU), Mamut, Sabah. East Malaysia. 1 1-14. viii. 198 1, K. Morimoto leg.

Distribution. East Malaysia (Sabah).

\section{Katsurazo sp.}

As mentioned above, this species is considered to be a congeneric in spite of its normal antennae and related to the type species. Because of the inconspicuousness. description on single specimen is withheld here until additional material is available for study.

Specimen examined. 1 male, Gunung Singgalang, (Sumatra's Westkust). 1800M. 1925, Leg. E.Jacobson (NMNH).

Distribution. Indonesia (Sumatra).

\section{Acknowledgments}

I dedicate this paper with gratitude to Dr. Katsura Morimoto on his retirement from Kyushu University. My interest in weevil research was exceptionally promoted by his warm leadership and excellent guidance as a supervisor. I much indebted to Dr. Christopher H. C. Lyal and Mr. Richard T. Thompson (BMNH) for their critical reading of the original draft of the manuscript, Dr. J. Krikken (NMNH) for his kindness in the loan of material, and to Prof. J. Yukawa and other staff of ELKU for their encouragement. I also thank Miss M. Idateyama, who prepared the drawing of Katsuraso morimotoi. This study is supported by a Grant-in-Aid from the Ministry of Education. Science, Sports and Culture, Japan and fund from the Japan Society for Promotion of Science for Japanese Junior Scientists.

\section{References}

Anderson, R.S., 1989. Revision of the subfamily Rhynchaeninae in North America (Coleoptera, Curculionidae). Trans. Amer. ent. Soc., 115: 207-3 12.

Kojima, H. and K. Morimoto, 1996a. Systematics of the flea weevils of the tribe Rhamphini (Coleoptera, Curculionidae) from East Asia IT. Phylogenetic analysis and higher classification. Esakia, (36): 97- 134.

Kojima, H. and K. Morimoto, 1996b. The tribe Ochyromerini (Coteoptera. Curculionidae) of Japan III. Genera with seven segments in the funicle and key to genera. Jpn. J. Ent., 64(4): 733-743.

Morimoto, K. and S. Miyakawa, 1996. Systematics of the flea weevils of the tribe Rhamphini (Coleoptera, Curculionidae) from East Asia I. Descriptions of new taxal and distribution data of some species. Esakia, (36): 61-96.

Marshall, G.A.K., 1957. Some new Indonesian Curculionidae. Tijdschr.Ent., 100: 61 65. 
Voss, E., 1940. Über Rüsselkäfer der Indomalayischen Subregion. vorwiegend von Java (Col., Curc.). Tijdschr. Ent., 83: 17-93.

Voss, E., 1953. Über einige in Fukien (China) gesammelte Rüssler, IV. (Col.. Curc.). Ent. Blätt., 49: 42-82.

Warner, R.E., 1961. The genus Ochyromera new to the western hemisphere, with a new species and additions to the Junk-Schenkling Coleopterorum Catalogus (Curculionidae: Prionomerinae, Endaeini). Coleopt. Bull., 15: 121 - 124. 